\title{
A LÓGICA DA COMPAIXÃO
}

Sandra CAPONI ${ }^{1}$

- RESUM 0: Tomando como ponto de partida os trabalhos de Nietzsche, Hannah A rendt e Michel Foucault, este escrito pretende problematizar a lógica interna da compaixão piedosa, pois, como tentaremos mostrar, ela parece instaurar uma modalidade peculiar de exercício de poder que se estrutura a partir do binômio servir-obedecer. A partir desses autores, pretendemos ler alguns exemplos que a história da humanidade nos apresenta para ilustrar o exercício dessa "cruel compaixão".

- PalaVRAS-CHAVE: Compaixão; Nietzsche; poder.

Interessa-nos problematizar a lógica interna da compaixão piedosa, pois, como tentaremos mostrar, achamos que ela instaura uma modalidade peculiar de exercício do poder que se estrutura a partir do binômio servir-obedecer, multiplicando assim a existência de relações sempre dissimétricas, entre quem assiste e quem é assistido. Se acreditamos que é necessário excluir do discurso médico a caridade cristã e a piedade religiosa, aquela que costumava situar o doente no lugar da debilidade mais absoluta e da mais extrema impotência, então será mister que possam ser desenvolvidas estratégias capazes de fazer que a palavra dos doentes possa formar parte de uma rede dialógica, que permita instituir um genuíno consenso, em que hoje existe aceitação passiva. Mas, para

1 Professora A djunta do Departamento de Saúde Pública da Universidade Federal de Santa Catarina S/C - Doutora em Lógica e Filosofia da Ciência - Unicamp. 
que este objetivo seja atingido, acreditamos que é preciso analisar a estrutura e o modo de funcionamento dessa compaixão piedosa.

Empreender uma crítica da ética da caridade e da compaixão exige que nos lembremos de Nietzsche (1984), pois é mérito seu ter sabido iniciar, com lucidez e firmeza, um estudo demolidor dessas estratégias de poder que, no preciso momento em que nos prometem auxílio e assistência, multiplicam os mecanismos de coerção, docilização e submissão.

As perguntas que Nietzsche faz a respeito da caridade e da compaixão podem ser resumidas nestas duas: "É conveniente ser antes de mais nada homens compassivos?"; "É conveniente para os que padecem que deles vos compadeçais?" (1984, p.338). A resposta a essas questões será, por sua vez, determinante: "Nossos benfeitores diminuem nosso valor e nossa vontade, ainda mais que nossos próprios inimigos".

0 que acontece é que eles estão impossibilitados, a partir do início, de interpretar corretamente em toda sua complexidade a dor de quem padece, e é ali que radica uma caraterística que define o compassivo: "pois o próprio do sentimento de compaixão é despojar a dor alheia do que ela tem de pessoal", de individual, de único e irrepetível. Quando o sentimento de piedade pretende superar este limite, ele se faz intolerável e é por isso que

na maior parte dos benefícios aos necessitados existe algo que indigna, pela indiferença intelectual com que o compassivo julga o destino, sem saber nada das conseqüências e complicações interiores que para mim e para você se chamam infortúnio. (Nietzsche,1984, p.338)

A pessoa compassiva tem o impulso de socorrer, quanto antes meIhor, mas o que não existe é o tempo para medir se as conseqüências desse socorro imediato são ou não desejadas por aquele que padece um infortúnio. Para Nietzsche, a figura do homem piedoso é a de alguém que não pode tolerar uma mínima margem de dor, que não pode desfrutar ou aprender de sua solidão, é alguém que

quer socorrer e não pensa que o infortúnio pode ser uma necessidade pessoal e que você e eu podemos necessitar tanto do terror, das privações, da pobreza, das aventuras, dos perigos, dos desenganos quanto dos bens contrários. (1984)

Enfim, trata-se de alguém cuja única religião não é a caridade, pois ele professa também a "religião do bem-estar", ficando assim impossibilitado de entender aqueles para os quais o bem-estar, seja ele imediato ou possível, longe de representar um valor, representa uma ameaça, algo assim como a calma que nada precede. 
É por isso que cotidianamente podemos assistir a imorais mas piedosas atitudes que, respondendo à força da compaixão e à procura do bem-estar, reproduzem a mais ilegítima, ainda que legalizada, coerção: aquela que pessoas caridosas exercem sobre os infortunados. Legitimase assim que, compulsoriamente, os homeless sejam deslocados para abrigos públicos reconhecidamente perigosos; admite-se que os ditos "loucos" sejam isolados em centros que, clara e indiscutivelmente, não são espaços de reabilitação ou cura; estimula-se que os "meninos de rua" sejam recolhidos em asilos para esperar uma adoção sempre diferida; interfere-se, piedosamente, na dissolução e separação de famílias carentes. As reflexões de Nietzsche, assim como as de Hannah A rendt e Thomas Szasz se defrontam com esses mecanismos obscuros e cotidianos, por meio dos quais a piedade e a compaixão se revelam como uma perigosa e temível tecnologia de poder que, no entanto, insiste em aparecer com a máscara de um desapaixonado e necessário "humanismo".

É provável que, cotidianamente, descubramos a existência desses espetáculos de coerção e submissão, mas a força da freqüência nada nos diz acerca dos motivos que levam esses homens e mulheres comuns e benfeitores a compartilhar a crença de que, por trás dessas inclinações caridosas, eles realizam atos morais e que é por meio dessas realizações que eles podem converter-se e afirmar-se como pessoas virtuosas. É preciso descartar a existência de um maquiavel ismo consciente que prefere se apresentar como compassivo para poder exercer assim, mais livremente, o domínio e o poder. Quiçá os motivos sejam mais simples, e é outra vez em Nietzsche que devemos procurar alguma resposta à pergunta pela conveniência em ser homens compassivos.

Veremos então que as conveniências são múltiplas:

O contratempo sofrido por outra pessoa nos ofende, nos faz sentir nossa impotência e talvez nossa cobardia, se não acudirmos em seu auxílio. ... Ou na dor alheia vemos algum perigo que também nos ameaça, pois ainda que só seja como sinais da insegurança e da fragilidade humanas, os infortúnios alheios podem produzir em nós penosos efeitos. Rejeitamos esse gênero de ameaça e de dor e lhe respondemos por meio de um ato de compaixão, no qual pode existir uma sutil defesa de nós mesmos e até algum resquício de vingança. (Nietzsche, 1978, p.133)

Em todos esses e outros fenômenos que se resumem na palavra "caridade", o que se evidencia é que, na realidade, "pensamos muito mais em nós mesmos que nos outros". 0 que fazemos no momento de realizar um ato de caridade é libertar-nos de um sentimento de dor que 
é absolutamente nosso, a dor que inspira o espetáculo da miséria, e o que fazemos então é libertar-nos de um padecimento, de um medo que é muito pessoal e muito nosso. Nesse sentido, Tomas Szasz dá um bom exemplo de como a compaixão não tem por que ser considerada como virtude: narra suas lembranças de Budapeste, a visão de amputados e indigentes, solicitando algumas moedas, e lembra esse sentimento de compaixão que então se apoderava dele.

Nesse ínterim - diz - dei-me conta de que minha generosidade não era de todo altruísta, que eu era motivado por um vago receio de que um destino semelhante pudesse recair sobre mim, aliado a uma esperança supersticiosa de que minha oferta pudesse evocar uma divindade com poderes misteriosos sobre esses assuntos. (1994, p.22)

0 problema aparece quando elevamos essa compaixão - que sabemos inútil e ineficiente, que reconhecemos como um pobre instrumento para suprir qualquer necessidade - ao nível de uma categoria moral ou social: quando acreditamos que a ela é capaz e eficiente a ponto de nos construir como agentes "morais", ou quando pretendemos fundamentar nela uma ordem social mais justa.

0 que está em jogo ali é a lógica interna da moral da compaixão. Uma lógica que, como já foi dito, pode e deve ser analisada como sendo a racionalidade própria de uma estratégia de poder. Como afirma Nietzsche:

ao realizar atos de caridade o que fazemos é libertar-nos de um padecimento que é nosso. No entanto, não agimos nessa direção impulsionados por um único motivo, e ainda quando seja verdade que queremos nos libertar de uma dor, também é verdade que agimos impulsionados pelo júbilo provocado pelo espetáculo de uma situação oposta à nossa, pela idéia de poder socorrer àquele infortunado se assim o desejarmos, pela esperança da gratidão que haveremos de obter pela atividade do socorro. (1978, p.133)

Ainda que nos horrorizemos perante a idéia desse júbilo, não é outra coisa que se evidencia na enunciação de algumas frases tais como: "deves sacrificar-te com entusiasmo", "deves imolar-te a ti mesmo". A moral da compaixão, que apregoa a entrega e a mortificação, detesta reconhecer que por trás de um ato de piedade e na própria entrega de si (quanto maior o sacrifício, maior a dívida gerada), o que se afirma é a existência de uma dívida que haverá de ser paga com eterna gratidão e com humildade. Por isso, sentimos o pior ressentimento quando alguém se nega a aceitar nosso sacrifício. 
0 homem caridoso satisfaz uma necessidade de sua alma fazendo o bem. Quanto maior for essa necessidade menos se posiciona no lugar daquele que socorre e que Ihe serve para satisfazer essa necessidade, e até reage duro e ofensivo em certos casos. (Ibidem, p.334)

Limitamo-nos aqui à tentativa de responder à primeira das duas perguntas formuladas por Nietzsche, aquela referida especificamente à conveniência em sermos homens compassivos. Para resumir, digamos que essa conveniência pode ser analisada como uma dívida que se impõe à pessoa auxiliada, e na medida em que se trata de uma dívida contraída por alguém, cuja condição é de precariedade extrema, esta retribuição esperada não haverá de ser outra que um estado de gratidão permanente. Porém, ao mesmo tempo o que ali está em jogo é uma perigosa tranqüilidade de consciência, que impossibilita a análise das conseqüências de nossas ações caridosas:

Em si própria a compaixão não tem de benfeitora mais do que qualquer outro instinto. Só quando a exigimos e a elogiamos - e isto acontece quando não se compreende o prejuízo que produz, quando é olhada como fonte de prazer - é que ela vem acompanhada da tranqüilidade de consciência e então nos entregamos a ela sem temer suas conseqüências. (Ibidem, p.134)

Fica ainda por delimitar em que consiste a conveniência de ser objeto de compaixão para aqueles que padecem.

Se quisermos aventurar alguma resposta a essa questão, não poderemos prescindir de uma problematização da distinção existente entre aquele que se compadece e aquele que é compadecido. Em outras palavras: entre aquele que se afirma, em seu gesto de entrega, como um benfeitor e aquele que, por receber assistência (ainda que esta não seja solicitada) se diz beneficiado. Essa distinção parece estar fundamentada em uma dissimetria que, na perspectiva de Nietzsche, é insuperável. Para ele, "compadecer-se equivale a depreciar". Por isso, "entre os selvagens, o homem pensa com terror em quais poderão ser as causas que 0 levariam a ser compadecido, pois isso seria considerado como prova de que ele carece de qualquer virtude" (Ibidem, 1978, p.134).

A partir do momento em que alguém pode manifestar piedade por outra pessoa, a caracteriza como sujeita a uma debilidade, como alguém que só pode superar suas limitações pelo socorro que a pessoa compassiva pode oferecer. Então, com um mesmo gesto se estabelece uma divisão binária entre aquele que se engrandece ao realizar a ação e aquele que se diminui ao recebê-la. Como já dissemos, conceder à compaixão, à 
caridade ou à piedade um valor moral pode levar a crer, erradamente, que ao socorrer os outros nos engrandecemos como agentes morais, e que, desse modo, podemos converter-nos em sujeitos moralmente inobjetáveis. Mas, é justamente esta ilusão, baseada no suposto eng randecimento "moral" de si, que impede pensarmos que, talvez, nosso gesto de compaixão não seja desejado; que quiçá ele possa ter conseqüências negativas para o "beneficiário"; ou que, simplesmente, possa gerar e promover estados de dependência e de submissão. Algo assim acontece quando sufocamos o doente com cuidados que ele próprio poderia assumir, quando pelo bem de algumas pessoas "inconvenientes" as preferimos excluir e medicalizar, quando acreditamos conhecer as necessidades e as demandas dos outros, muito antes de que elas possam ser solicitadas. Nesse jogo perverso, 0 infortúnio do semelhante corre o risco de converter-se em "edificante" para os seres compassivos. Então, pode tornar-se viável esse irônico e implacável aforismo nietzscheano:

quando um homem é infortunado, acodem as pessoas piedosas e lamentam seu infortúnio. Quando elas saem, no fim satisfeitas e edificadas, ficaram fartas do espanto do infortunado, como se se tratara de seu próprio espanto, e passaram uma boa tarde. (Ibidem, 1978, p.224)

Sendo assim, parece que não pode existir nenhum espaço reservado para alguma forma legítima de compaixão. Podemos, então, formular algumas perguntas: será que sempre e fatalmente depreciamos 0 beneficiário de nossa piedade? Não existe um sentimento legítimo pelo qual me reconheço como igual ao outro, no momento em que me compadeço de seu sofrimento? A parentemente não é possível responder afirmativamente a nenhuma dessas questões se tomarmos como ponto de partida 0 aforismo nietzscheano antes citado. Porém, haverá de ser 0 próprio Nietzsche quem fornecerá um suporte para refletir sobre um modo legítimo de piedade. Este pode ser um sentimento capaz de gerar vínculos positivos e moralmente legítimos, só em certos casos singulares: ali onde exista proximidade e identificação com essa pessoa que consideramos como infortunada.

Então, quando um amigo admirado ou um inimigo respeitado viverem uma situação de infelicidade ou se vejam forçados a padecer algum tipo de sofrimento, é que minha compaixão pode ser definida como legítima, pois ali é minha própria desgraça que sofro. Isso poderá acontecer cada vez que, por causa de um infortúnio, deva enfrentar a privação desse afeto e dessa amizade que me alegra e gratifica. Mas também pode existir um modo legítimo de piedade quando vejo "padecer um 
inimigo a quem considero um igual em orgulho e a quem o tormento não derrota, e em geral quando vemos padecer a um ser que não quer pedir compaixão, que é, a humilhação mais vergonhosa e mais baixa" (Nietzsche, 1978, p.324). Ali parece que nos enfrentamos com um sentimento próximo da admiração, mas que, no entanto, não pode ser intei ramente separado de uma forma de piedade que é menos "compassiva" do que "apaixonada". 0 que diferencia este sentimento legítimo da piedade compassiva é que não existe nada ali que possa ser associado ao desprezo; muito pelo contrário, ele se funda em um sentimento que é próximo da admiração. Esse infortúnio não nos enaltece nem nos faz mais humanos ou mais virtuosos, simplesmente nos iguala com aquele que padece. Ainda em tais circunstâncias, é possível afirmar com Nietzsche que em si mesma "a compaixão não tem de benfeitora mais que qualquer outro instinto", que não é esse sentimento que nos faz mais virtuosos ou morais, mas sim os atos que de fato somos capazes de realizar. A compaixão assim como pode gerar atos virtuosos também pode representar uma debilidade moral. É assim como os estóicos a vêem: para eles não existe distinção entre a piedade e a invídia: "Pois o homem que se compadece de outro, também pode ficar aflito pela prosperidade dos outros" (Szasz, 1994, p.25).

Mas, a piedade é sempre uma debilidade

para aquele que, num sentido ou noutro, quer servir de médico à humanidade. Ele tem que tomar precauções contra esse sentimento que o paralisa nos momentos decisivos, que ata sua consciência e sua mão hábil. (Nietzsche, 1978, p.134)

Enfrentamo-nos com um sentimento que não é, em si próprio, nem bom nem ruim, mas, no momento em que ele é exigido e exaltado como um valor moral, na medida em que fazemos desse sentimento uma reg ra de comportamento, capaz de definir por si própria um parâmetro do que é moralmente desejável para um grupo humano, corremos o risco de legitimar certas estratégias de coerção que se exercem em nome e pelo bem dos considerados beneficiários.

\section{Sociedades compassivas}

A história da humanidade apresenta muitos exemplos que podem ilustrar o exercício dessa "cruel compaixão", e quiçá o primeiro deles é a implementação, na Inglaterra, das 43 leis de Isabel, também conheci- 
das como "Lei de Pobres". Tanto na sua implementação, por meio da organização e administração paroquial, que caracterizou a Inglaterra dos séculos XVII e XVIII, quanto na sua posterior revisão e reformulação, a Lei de Pobres representa o mais antigo e o mais claro exemplo de coerção compassiva.

É pela força da caridade e da compaixão que o mundo da pobreza começa a ser racionalizado e quadriculado, e que se pode começar a estabelecer diferenças e categorias entre os habitantes daquilo que, até este momento, formava parte do contínuo "pobres". Para assistir e auxiliar os pobres foi mister, em primeiro lugar, designar lugares e funções, distribuir e fixar a cada um dos necessitados um espaço preciso. $\mathrm{Na}$ medida em que cada paróquia era a responsável pela administração e gestão deste auxílio, foi indispensável que, ao mesmo tempo em que se socorria e se cuidava, fosse procurado um meio para fixar cada indivíduo dentro do espaço daquela que seria sua paróquia benfeitora. Surge assim, dentre as 43 leis, a famosa Lei de Assentamentos, que impedia que qualquer habitante do mundo da pobreza pudesse deslocar-se em direção a outros centros; exceto se ele pudesse demonstrar que poderia pagar, dentro do prazo de 40 dias, o aluguel de uma moradia "digna", cujo valor não fosse inferior a 10 libras.

É evidente que em circunstâncias nas quais a maior parte dos trabalhadores necessitava, em algum momento, de auxílio paroquial (seja por doença ou por falta de emprego), a Lei de Assentamentos transformava-se num instrumento de imobilização da força de trabalho. Nessas circunstâncias em que os conceitos de "trabalho" e de "pobreza" eram quase sinônimos, pois era inevitável a oscilação existente entre o trabalho e a desocupação, essa lei parecia reivindicar para si o direito e 0 dever de constituir-se numa instância legítima de controle e de coerção social, que tinha por objeto vigiar essa metade "baixa" da população que, estranhamente, era caraterizada como aquela que "diminui a riqueza do reino".

Um bom exemplo desse controle primitivo constitui uma lei conhecida com o absurdo nome de "lei da letra P". Ela obrigava todos os pobres que gozavam do privilégio da assistência, ou que pudessem, eventualmente, necessitar desse auxílio, a levarem um distintivo: a letra " $P$ " num tamanho claro e legível, pintada nas costas dos agasalhos. A utilidade dessa lei parece ser simplesmente ritual, pois a limitação da liberdade de deslocar-se de uma paróquia a outra, dificilmente poderia ser controlada pelo uso de uma letra que unificava a todos e a cada um dos "beneficiários" do auxílio estatal. 
Essa persistência, essa continuidade no tempo, de diferentes modos de auxílio aos pobres que eram administrados e unificados por meio da ação caridosa das paróquias, encontra sua razão de ser e sua lógica nessa figura confusa e equívoca da "compaixão piedosa". Isso não implica afirmar que fosse um auxílio inútil. Sem dúvida, ele fez o possível para que pessoas pobres pudessem gozar do direito irrenunciável e irrecusável de satisfazer suas necessidades elementares. Trata-se aqui de evidenciar a outra face do socorro, de mostrar que a ação piedosa das paróquias fez o possível para que o mundo da pobreza fosse invadido, diferenciado, classificado e fixado em um espaço preciso. Como afirma Foucault:

com a Lei de Pobres emerge, de maneira ambígua, um importante fator na história da medicina social: a idéia de uma assistência fiscalizada, de uma intervenção médica que constitui um meio de auxiliar os pobres a satisfazer necessidades de saúde que, por sua pobreza, não podiam atender e que, ao mesmo tempo, permitiria manter um controle pelo qual as classes endinheiradas garantiam ... a proteção de uma faixa privilegiada da população. (1993, p.146)

Por muito tempo, tanto na Inglaterra quanto em outros países europeus, a assistência e o cuidado dos pobres ficou por conta da figura da "mulher consagrada", que antecede à figura da enfermeira que, como tal (isto é: desvinculada de funções religiosas), só aparecerá na segunda metade do século XIX. Entre os pobres de Deus, que se beneficiam da caridade e das mulheres benfeitoras, não existe nada semelhante a um "intercâmbio" no qual se reconheça a independência ou a igualdade dos agentes. Todas as relações que ali aparecem, pertencem, sempre e necessariamente, ao registro do "dar" e do "receber": acredita-se que existe, por uma parte, a necessidade e, por outra, assume-se a existência do supérfluo.

Por meio dessa dissimetria anula-se toda reciprocidade, porém, se alimenta, ao mesmo tempo, uma necessidade de reconhecimento. Os pobres de Deus: "estão sempre em dívida com o bem que lhes é feito e não tomam consciência da dependência em que são mantidos" (Colliére, 1989, p.71). Encontramos justamente ali um risco que é inerente à figura da mulher benfeitora: na medida em que centra todos os seus cuidados e toda sua atenção na pobreza, pode correr o perigo de reforçar esse sofrimento e essa pobreza, convertendo-os num mal que é necessário para poder exercer 0 bem.

Hospícios e hospitais são estações obrigatórias no trajeto de assistência generalizada, verdadeiras bases de apoio de uma política de quadrícula difusa das famílias e observatório privilegiado das espécies e das formas de indigência (De Gerando, 1977, p.89). 
A mulher consagrada contribui, assim, em estabelecer as demarcações e classificações que desarticulam o antigo "contínuo pobres", em diferentes tipos de pobreza: a digna e a indigna, a laboriosa e ociosa, a doente e a saudável, enfim, a pobreza considerada normal e aquele estado patológico que devia ser assistido e normalizado. Demarcações que adotaram um estatuto jurídico com a assim chamada Nova lei de pobres. Foi só, em 1843, quando essa lei foi promulgada, que aquela Lei de Assentamentos foi derrogada. 0 certo é que, ainda dentro de um marco completamente contrário às necessidades que as novas demandas industriais impunham, a Lei de Assentamentos pôde persistir por mais de dois séculos. Essa lei só foi derrogada no mesmo momento em que se excluíam os pobres adultos e saudáveis, capazes de trabalhar, de qualquer outro modo de auxílio que não fossem as Work-houses.

Mas, o que era esta Lei de Pobres que marcou o início da chamada "Época da Bondade"? Ela se definia como uma lei capaz de garantir: "trabalho para os que querem trabalhar, castigo para os que não querem e pão para os que não podem" (Himmelfarb,1986, p.40). Entre os beneficiários incluíam-se, inicialmente, tanto os pobres dependentes quanto os independentes, os pobres dignos quanto os indignos, os que deviam ser castigados e os que deviam ser auxiliados. A diferença entre eles só se estabelecia pelo tipo de auxílio a que tinham direito, ainda quando essas distinções nunca ficaram completamente claras.

Em princípio, todos os pobres habitantes de Inglaterra, em algum momento, eram beneficiários da caridade, ainda quando existiam diferentes tipos de auxílio para os diferentes tipos de pobres: "esmolas e asilos para os idosos e doentes, aprendizado de ofícios e escolas de caridade para as crianças, castigo e clausura para os 'andarilhos teimosos', e trabalho para os sadios" (Ibidem, p.33). Surgiram então os "A silos de Pobres" onde achavam seu socorro tanto os velhos quanto os doentes, os inválidos quanto os soldados desertores, as crianças abandonadas e as pessoas sem lar. Por sua vez, os regulamentos quase religiosos das Workhouses, em que mulheres e homens eram empregados para trabalhar, trocavam moradia e comida pela imobilidade a que os sujeitava um salário só pago depois de um ano de labor. Multiplicaram-se por toda Inglaterra as escolas de caridade onde, conforme explica Thompson, dificilmente as crianças puderam atingir algo mais do que rudimentos de escrita e de leitura centrada na Bíblia.

Um de seus mais acérrimos críticos, Mandeville, afirmava que, sendo tão pouca a influência moral que a educação tinha entre os ricos, seria inútil e desatinado pretender estendê-la aos pobres: 
Para fazer a sociedade feliz e para que o povo ficasse sossegado nas piores circunstâncias, requer-se a existência de grande quantidade de ignorantes e pobres. 0 conhecimento acrescenta e multiplica nossos desejos, e quanto menos coisas deseje o homem, mais facilmente pode satisfazer suas necessidades. (Himmelfarb, 1986, p.39)

Essas críticas de M andeville não eram nem comuns nem aceitas na chamada "Época da Bondade". Esse cinismo conservador, que ainda hoje existe, irritava os homens sensíveis da Inglaterra que, no entanto, conseguiram dar resposta a essas críticas, num tom que se iguala em brutalidade e cinismo. Os defensores das escolas de caridade escolheram dar uma resposta sincera:

Os pobres, longe de serem corrompidos pela educação, aprenderão a tolerar sua pobreza com maior fortaleza, serão dissuadidos a levar uma vida de dissipação e delito e aprenderão as virtudes e as habilidades, que os tornarão melhores operários e melhores pessoas. (Ibidem, p.40).

De fato, todos os projetos filantrópicos desse período se caracterizam pela sua ambigüidade. Se de um lado eles se apresentam como uma forma de assistência caridosa dirigida aos necessitados, de outro se propõem como dispositivos de controle e coerção social. Esses dois exemplos imaginados por William Petty podem ser significativos: o projeto de criar um hospital para apestados que fosse semelhante a um leprosário, isto é, uma instituição de isolamento e exclusão; e o projeto de criar uma maternidade para mães solteiras pobres, que seria um benefício para o Estado: este tomaria a seu cargo a assistência e a proteção das mães, mas imporia como forma de pagamento que os filhos ali nascidos ficassem nas suas mãos durante 25 anos, contribuindo para acrescentar suas reservas (Rosen, 1980, p.225). Mesmo que esses projetos nunca tenham sido aprovados, é significativo que fossem imaginadas instituições filantrópicas que unificavam, de um modo tão evidente e pacífico, a caridade e o controle social.

A necessidade e sujeição dos pobres necessitados é, por si própria, uma garantia de obediência, porém, ela representa

também a impossibilidade, a incapacidade de se situar numa relação de paridade e a possibilidade de evitar ter que enfrentar diversas formas de relacionamento social que exijam julgamento e discernimento. (Colliére, 1989, p.68)

Assim, poderemos observar que a mulher consag rada pode complementar um imperativo inalterável de respeito por aqueles que sabem, com uma exigença de submissão e de aceitação que é explicitamente 
reconhecida como a outra face da assistência e do cuidado. É ali, na submissão e na gratidão daqueles que ela cuida, em que a benfeitora encontra uma compensação afetiva e social.

0 pobre desamparado é, antes de tudo, a garantia de uma eterna obediência; e assim, na dedicação e na entrega de sua vida aos pobres, a mulher consagrada encontra a razão de sua existência.

A compensação de tanta abnegação pode encontrar-se numa valorização espiritual e social importante que Ihe permite, sem dúvida, encontrar a força para assegurar a sua tarefa ... É assim que pode realizar a sua função materna, sublimada numa maternidade espiritual dos doentes a tratar, dos pecadores por quem é preciso rezar. (Colliére, 1989, p.68)

\section{Compaixão apaixonada}

Alguma coisa unifica a todos e a cada um dos benfeitores: "Os bons sentimentos", a compaixão pelos doentes. Ou como diria Rousseau (1984): "uma repugnância inata em ver o sofrimento de um semelhante". É assim que os filantropos ingleses se unificam com os revolucionários franceses, no momento em que se identificam com aqueles princípios que Rousseau isolou e caracterizou melhor que qualquer outro pensador. A partir de Rousseau, o interesse e a preocupação pelos outros viram uma paixão. Segundo a tese de G. Himmelfarb (1986), essa prioridade concedida à compaixão está longe de ser exclusiva de Rousseau; para ela, os filósofos morais ingleses, os filantropos, também sustentaram seus projetos e idéias "na benevolência, no humanismo, na simpatia, e nos afetos sociais: eles até usaram a palavra 'compaixão', no mesmo sentido".

Como Rousseau (1984), eles situaram esse sentimento no coração da natureza humana, convertendo-o no atributo característico mais importante da humanidade, e encontrando evidências em todas as esferas da vida (Himmelfarb, 1986, p.48). É verdade que os filósofos ingleses souberam sublinhar o caráter desinteressado e solidário da compaixão, porém, muitos dos projetos defendidos pareciam silenciar seu caráter igualador e solidário, reforçando, em troca, sua face mais coerciva. E isso não é um dado secundário; como dissemos: no preciso momento em que a compaixão e a piedade se convertem em parâmetros de moralidade, no preciso momento em que faço extensivo um sentimento, que só pode existir na intimidade (entre sujeitos que se reconhecem semelhantes), para 0 largo mundo dos pobres ou dos sofredores, a piedade perde seu caráter de sentimento legítimo e se torna uma eficaz estratégia de poder. 
Hannah A rendt soube resumir em poucas palavras os perigos próprios da sobrevalorização da compaixão e da piedade:

A piedade, tomada como fonte de virtude, tem demonstrado possuir uma capacidade para a crueldade, maior do que a própria crueldade. "Par pitié, par amour pour l'humanité, soyez inhumains". (1990, p.71)

Foi isso o que legitimou, para A rendt, o exercício do terror nos anos que sucederam à Revolução Francesa, crueldade que ficou para sempre associada com o nome de Robespierre. Para ele, a ação política deveria sustentar-se "naquele impulso imperioso que nos atrai para les hommes faibles", nessa capacidade de "sofrer com a imensa classe dos pobres" (Arendt, 1990, p.60).

Certamente, essa valorização da piedade como fonte de toda virtude é uma herança do pensamento de Rousseau; mais especificamente, provém das teses sobre a "comiseração" que aparece em 0 discurso sobre a origem da desigualdade entre os homens. Para ele, todos os valores humanos e todas as virtudes sociais derivam de uma única virtude que é a compaixão.

Com efeito, que são a generosidade, a clemência, a humanidade, mais do que a piedade aplicada aos fracos, aos culpados ou à espécie humana em geral? ... Ainda quando fosse verdade que a comiseração não é mais do que um sentimento que nos posiciona no lugar daquele que sofre, sentimento escuro e vivo no homem selvagem, desenvolvido, porém mais fraco, no homem civilizado. (Rousseau, 1984, p.93)

Perante a razão que isola, que estimula o amor próprio e o egoísmo, Rousseau venera a força niveladora de uma paixão primitiva e natural, a mais selvagem de todas as paixões, pois é o "sentimento primeiro de toda a humanidade". A piedade auxilia os homens racionais a moderar seu amor próprio, e à medida que se trata de um sentimento natural, desnuda a valentia dos mais simples: "a ralé, as mulheres da feira, são as que separam os combatentes, as que impedem os homens decentes seu mútuo extermínio" (Rousseau, 1984, p.94).

Perante essa ousadia da piedade, e como sua outra face, obscura e covarde, Rousseau decide situar a racionalidade sob a figura do filósofo que prefere tapar seus ouvidos ao clamor do sofrimento alheio e "argumentar um pouco para impedir a natureza que nele se subleva que 0 identifique com o assassino". Esses e outros exemplos falam da grandiosidade dessa virtude natural que é a piedade, ela nos leva "sem 
reflexão, ao socorro dos outros" (Ibidem), ao auxílio imediato e não refletido daquele que vemos sofrer. No momento em que esse ser que sofre já não é um sujeito individual e próximo, quando os sofredores são o conjunto de um povo chamado também de "pobres", "miseráveis", "homens fracos", "desgraçados", esse socorro imediato e irrefletido quase inevitavelmente se converterá numa escusa, para legitimar a violência.

Em sua exaltação da piedade como virtude, Rousseau se opõe ao pensamento grego. No Discurso, podemos ler que

Ainda que possa corresponder a Sócrates e aos gênios de sua têmpera a aquisição da virtude pela razão, faz muito tempo que 0 gênero humano não existi ria se sua conservação tivesse dependido exclusivamente dos razoamentos dos indivíduos que o compõem. (Rousseau, 1984, p.95)

\section{Contra essa afirmação}

A história diz-nos que de modo algum é uma coisa natural que o espetáculo da miséria mova os homens à piedade; mesmo durante os longos séculos em que a religião cristã de misericórdia impôs padrões morais à civilização ocidental, a compaixão se manifestava fora do domínio político. (A rendt, 1990, p.56)

M as voltemos agora aos gregos e lembremos que segundo A ristóteles

Nem as virtudes nem os vícios são paixões, pois não somos chamados de bons ou de maus em razão de nossas paixões ... Pois aquele que vive conforme manda a paixão não ouvirá argumentos que venham a dissuadi-lo, nem os compreenderá. ... A paixão parece conduzir, não ao argumento, mas à força. (A ristóteles, 1980)

Como Hannah A rendt soube mostrar, a esfera de discussão e diálogo, o jogo de perguntar e responder, faz parte desse âmbito da existência que os gregos isolaram como o âmbito do "propriamente humano". Ele define-se por um modo de existir entre iguais, que exige 0 uso dessas artes que são a dialética e a retórica. Por isso, Aristóteles acrescenta à definição de homem como zoon politicón, uma segunda especificação pela qual o homem pode ser pensado como Zoon Logon ekhón, isto é: ser vivo capaz de discurso.

A pólis era esse espaço onde tudo devia ser enunciado, onde a violência podia ser excluída para o exterior de seus muros. "Para o modo de pensar grego, obrigar as pessoas pela força, mandar em lugar de persuadir, eram formas pré-políticas para tratar com pessoas cuja existência estava nas margens da Pólis" (A rendt, 1993, p.33). Certamente era isso 0 
que permitia aos gregos conviver com formas despóticas de organização, como a escravidão ou o patriarcado. Coexistiam assim espaços onde regia a violência muda junto com espaços de diálogo entre iguais, que eram considerados como a esfera do propriamente humano. Escravos, bárbaros e mulheres eram aneu logou (sem logos); e claro que isso não significa que eles estivessem "desprovidos da faculdade do discurso, mas sim de uma forma de vida na qual o discurso e só ele tinha sentido, e onde a preocupação primeira entre os cidadãos era falar entre eles" (Ibidem, p.44).

Segundo H. A rendt,

os filósofos gregos, seja qual for sua posição a respeito da Pólis, não duvidaram de que a liberdade se localiza exclusivamente na esfera política, que a necessidade é de maneira fundamental um fenômeno pré-político ... e que a força e a violência se justificam nessa esfera porque são os únicos meios para dominar a necessidade e chegar a ser livres. (1993, P.41)

Ali está a maior dificuldade em pensar a compaixão dentro da esfera da política. Ela permanece alheia a esse âmbito que é próprio do diálogo entre iguais. Pretende superar uma necessidade que é urgente e imediata. Enfrenta-se com o sofrimento e com a miséria, mas não com o sofrimento singular de determinado indivíduo, com o qual me posso identificar, mas sim com o sofrimento de um grupo, aquele dos chamados "miseráveis".

Superar esse sofrimento por meio da compaixão significa excluir o diálogo e a argumentação da cena política e substituí-los pela imediatice da força. Implica também sair do âmbito da liberdade para ing ressar no registro da violência, pois essa esfera da liberdade estava signada pela palavra, pelo diálogo entre iguais, um diálogo que nem sempre significava harmônica convivência, mas, sim, exclusão de formas pré-políticas e mudas de violência.

Para o pensamento de Rousseau (1984) e daqueles que levaram seus ensinamentos para a cena política, era preciso liberar a mais primitiva e natural das paixões humanas dos grilhões que a razão impõe, então poderia lograr-se que essa "repugnância inata em olhar o sofrimento de um semelhante" possa substituir a indiferença reinante. Como já assinalamos, é pela razão que, para Rousseau, o homem se transforma em "egoísta" e perde sua capacidade para "se identificar com o infortunado" (A rendt, 1990, p.63). Da perspectiva de A rendt, só se pode concluir que a capacidade de refletir nos isola e nos faz despreocupados em relação aos outros, porque se desconhece que o pensamento político é essencialmente representativo, que é um diálogo sempre 
mediatizado por "numerosos pontos de vista que tenho presentes em meu espírito, no momento em que avalio uma questão; e, quanto meIhor posso imaginar de que modo sentiria se estivesse no lugar desses outros, tanto mais forte será minha capacidade de pensamento representativo (Ibidem, 1992, p.300). 0 que caracteriza nosso pensamento é seu caráter discursivo, a possibilidade de deslocar-se de um ponto de vista até outro, passando por pontos de vista diferentes e antagônicos tentando atingir uma generalidade imparcial.

0 pensamento, longe de isolar-nos na interioridade do eu, nos obriga a fazer um esforço por integ rar posições diversas, por imaginar como atuaríamos no lugar dos outros. Ele estabelece um diálogo com aqueles outros que estão presentes em meu espírito, quando aval io uma questão, embora isso não implique que devamos recorrer ao sentimento de "empatia". Existe uma única condição para esse processo de "formação de uma opinião refletida" que é o desinteresse, a libertação de nossos interesses privados, ou a capacidade de tornar minha posição o mais universal possível.

A diferença do que acontece com o pensamento político, a compaixão nunca pode ir para além do individual, ela implica essa capacidade de sentir, na própria pele e no próprio corpo, o sofrimento alheio: "como se fosse alguma coisa contagiosa" (A rendt, 1990, p.67). A compaixão caracteriza-se, como foi explicitado a partir de Rousseau, por

uma aversão a qualquer espécie de diálogo conciliatório e argumentativo, onde alguém fala com outro sobre alguma coisa que é de interesse de ambos. Esse interesse no mundo, loquaz e argumentativo, é inteiramente alheio à compaixão, que se dirige unicamente e com veemente intensidade ao próprio homem que sofre. (A rendt, 1990, p.67).

Ela é sempre e necessariamente um co-sofrimento que não pode ir além do padecimento de um semelhante.

A compaixão apaga as diferenças, elimina o espaço material que separa os homens entre eles, aproxima as pessoas, não pela palavra, mas sim pelos gestos ou pelos silêncios. "Sua força reside na força da própria paixão, que, diferentemente da razão, só pode olhar para o particular, pois não possui noção do geral nem capacidade de generalização" (Ibidem, p.70). Para que esses gestos e silêncios possam resultar significativos é preciso que esse co-sofrimento associe entre si os sujeitos que se reconhecem como semelhantes. Só então, como diz Nietzsche, estaremos diante de uma compaixão legítima, em que não existem relações dissimétricas, em que os vínculos não encontram seu fundamento no 
desprezo, mas sim na admiração.

Essa legitimidade nunca poderá exceder legitimamente o vínculo que se estabelece entre duas pessoas que se reconhecem mutuamente como iguais em orgulho e dignidade. Mas, aqui nos interessa problematizar esse preciso momento no qual a compaixão se faz extensiva às relações sociais, esse momento em que um sentimento privado, às vezes legítimo e outras ilegítimo, ingressa no âmbito do público.

Hannah A rendt nos propõe estabelecer uma distinção entre os conceitos de "compaixão" e "piedade" que pode auxiliar na compreensão desta questão. Para ela, só é possível falar de compaixão quando existe esse vínculo imediato a que já fizemos referência. Então fica "eliminado o espaço material entre os homens, onde se localizam os eventos políticos e todo o universo das relações humanas". Isso implica afirmar que a compaixão é "do ponto de vista político, irrelevante e sem conseqüências" (Ibidem, p.68). Para ela, as conseqüências negativas dessas atitudes compassivas que, no momento em que se propõem assistir e auxiliar, reforçam a coerção e a submissão não são mais do que seu efeito inevitável.

Efetivamente, não será a partir da compaixão que podem ser iniciadas modificações reais nas "condições materiais", capazes de aliviar o sofrimento das pessoas. $E$, no momento em que se pretende fazê-lo, é inevitável que sejam

eliminados os extenuantes processos de persuasão, negociação e acordo, que são próprios da lei e da política, e que se empreste a voz ao próprio sofrimento, que clama por ação direta e rápida, isto é, ação com os meios da violência (Ibidem, p. 79)

Chegamos assim, por uma via argumentativa absolutamente diferente à de Nietzsche, aos limites e riscos inerentes a uma exaltação moral da "compaixão".

Se a compaixão só pode referir-se ao singular, é a "piedade" que assume a função de generalizar esse sentimento às grandes massas de "sofredores". A piedade diferencia-se da compaixão na medida em que não se trata de uma paixão que seja vivida no próprio corpo, mas sim de um sentimento que, como tal, pode encontrar nele próprio seu prazer. Mas, por isso, ela pode ser também a perversão da compaixão no momento em que, ao desalinhar essa figura próxima do co-sofrimento, ao ampliar seu horizonte para o mundo dos "fracos", inevitavelmente corre o risco de glorificar essa mesma debilidade que a faz existir.

A piedade, ao contrário da solidariedade, não considera da mesma maneira a 
fortuna e o infortúnio, o forte e o fraco; sem a presença do infortúnio, a piedade não pode existir, e, portanto, tem exatamente o mesmo interesse na existência dos infelizes, que a sede do poder na existência dos fracos. (Ibidem, p.71)

A própria existência da miséria alimenta a piedade, na medida em que é pela grande massa dos que sofrem que este sentimento encontra seus alicerces e sua razão de ser. Na verdade, as relações que se estabelecem na base da piedade serão sempre e necessariamente dissimétricas, pois já não existe um local reservado, como no caso da compaixão, para um vínculo legítimo.

Na medida em que a piedade estende ao âmbito do público um sentimento que pertence inicialmente ao privado, se torna indispensável que ela saia da "obscuridade do coração", na qual encontrava seu local, e fique exposta ao mundo público. A compaixão que, como vimos, pretendia ser refratária a todos os argumentos e palavras, precisa ser enunciada quando entra no mundo das relações sociais sob a forma de piedade. M as assim, a declamação de que cada ato que se realiza está motivado num sentimento piedoso, faz aparecer a suspeita da falsidade, da mentira e da hipocrisia. Sabemos que, quase inevitavelmente, a enunciação pública da própria bondade é a forma mais usual de ocultar outras "motivações sub-reptícias". Sabemos também que são muitos os sentimentos, entre eles a compaixão, que, na medida em que permanecem ocultos podem ser corretos, mas que deixam de sê-lo no momento preciso em que decidimos comunicá-los publicamente, e então começam a ter o gosto desagradável da "hipocrisia".

Declamar nossa bondade, torná-la pública, parece legitimar nosso direito a exigir que os outros reconheçam, também, suas motivações ocultas. Porém, todos ficam assim, sob suspeita: tanto aquele que declara suas motivações bondosas, altruístas e piedosas como aquele que prefere calar e reservar suas paixões, sejam elas compassivas ou não, ao silêncio do privado. Como afirma A rendt:

A exigência de que todos anunciem em público suas motivações íntimas transforma a todos os atores em hipócritas; no instante em que se inicia a exibição dos motivos, a hipocrisia começa a envenenar as relações humanas. Ademais, o esforço por arrancar o que está obscuro e escondido para a luz do dia só pode resultar numa livre e ruidosa manifestação daqueles atos cuja própria natureza os leva a procurar a proteção da escuridão. (Ibidem, p.79)

Cabe agora repetir a pergunta que formulávamos acima: se a compaixão só pode ser legítima no vínculo imediato, nesse reconhecimento que existe entre iguais, e se a piedade pode ser considerada sua perversão 
(na medida em que pretende estender esse co-sofrimento às grandes massas dos sofredores), resulta disso que não existe nenhum princípio capaz de guiar ações tendentes a diminuir ou anular o sofrimento alheio? A alternativa à piedade, como perversão da compaixão, é para Hannah A rendt (1990) a solidariedade. Já não se trata de um sentimento que leve em si próprio seu prazer; nem de uma atração pelos homens fracos que reforce a polaridade entre posições dissimétricas. A solidariedade encontra seu fundamento na simetria dos interesses, numa "desapaixonada comunidade de interesses" com os infortunados, na medida em que todos compartilham uma única preocupação por universalizar a "dignidade humana". Assim, ainda que uma ação eficaz possa ser motivada pelo sofrimento, nunca é por ele guiada, pois ela deve compreender:

tanto os fortes e os ricos, quanto os fracos e os pobres. Comparada com o sentimento de piedade, ela pode parecer fria e abstrata, pois permanece mais comprometida com "idéias" - grandeza, ou honra, ou dignidade - do que com qualquer "amor" pelos homens. (Ibidem, p.70)

A solidariedade supera o vínculo imediato do co-sofrimento na medida em que ela não é nem silenciosa nem gestual, mas sim precisa da mediação das palavras e do diálogo, para poder generalizar-se. É próprio da compaixão e da piedade igualar, borrar as diferenças entre os que sofrem, unificá-los sob o nome de infortunados; pois, como afirmaria Nietzsche, "o próprio do sentimento de compaixão é despojar a dor alheia do que ela tem de pessoal", de individual e irrepetível. A solidariedade procura, em troca, tomar como ponto de partida as diferenças, uma pluralidade humana considerada irredutível. Perante a impossibilidade de falar de uma natureza que nos unifique, ou que unifique os que sofrem, A rendt pensa a condição humana em função da categoria da "pluralidade". "A pluralidade é a condição da ação humana, pois todos somos o mesmo, isto é, humanos, e portanto, ninguém é igual a qualquer outro que tenha vivido, viva ou viverá jamais" (Arendt, 1993, p.22). Porque existe diferença, mais do que identidade essencial, a ação e o diálogo não são luxos não necessários, mas sim elementos constitutivos deste nós que somos. A condição humana pode realizar-se a partir do momento em que participamos do âmbito da vida ativa, em que os vínculos devem ser sempre, e necessariamente, mediatizados pela palavra (único modo de garantir a exclusão da violência).

Por fim, resta dizer que outorgar prioridade à solidariedade sobre a piedade, à monotonia do diálogo entre iguais, sobre a aparente luz do sentimento, nos permite excluir qualquer forma de glorificação da misé- 
ria e, conseqüentemente, qualquer interesse sentimental em sua existência. "Por tratar-se de um sentimento, a piedade pode encontrar em si própria seu prazer, isso leva, quase que automaticamente, a glorificar sua causa: o sofrimento alheio" (A rendt, 1990, p.71). A ssim, e pela patética lógica da piedade, a miséria e o sofrimento deixam de ser obstáculos que devem ser superados tecnicamente para se converter em uma realidade triste, que devemos tolerar. Pois, em virtude de sua existência, o compassivo pode se reconhecer como um sujeito benfeitor, se regozijar no prazer que decorre de sua bondade filantrópica e caridosa. Pela lógica perversa da piedade, a miséria legitima a mesma dissimetria de poder que a gerou.

\section{Assistência e piedade}

Acreditamos que essa glorificação do sofrimento alheio, que faz da dor e da miséria elementos necessários para que o benfeitor seja reconhecido como um agente moral, se faz evidente na assistência médica sempre que ela se apresenta sob a forma de um "socorro" ou um "auxílio compassivo" a quem sofre. Nesse sentido parece-nos obrigatória uma remissão ao texto de Thomas Szasz (1994), Cruel compaixão. Ali, 0 autor tematiza as ambivalências e os perigos que inevitavelmente parecem associar-se com diversas formas de assistência compulsiva referidas a uma figura paradigmática: o "adulto fisicamente capaz mas improdutivo" (Ibidem). São desmontados ali, pouco a pouco, esses mecanismos obscuros, históricos e cotidianos, pelos quais a piedade se revela como uma perigosa tecnologia de poder que, porém, gosta de se apresentar com a máscara de um desapaixonado e inevitável "humanismo".

Para que essa piedade possa ser exercida com a ferocidade e o rigor que lhe são próprias, será necessário que possa fazer do doente (Szasz se refere à doença mental) um sujeito desprovido dos direitos elementares. Inicia-se então um processo pelo qual as consideradas "patologias" serão caracterizadas e classificadas de modo ambíguo como um padecimento que infantiliza os homens. Assim, os doentes mentais, considerados como crianças, passam a ser tratados como alheios a qualquer obrigação, e conseqüentemente, a qualquer direito. Pode resultar assim politicamente legítimo pensar esses doentes-crianças como não responsáveis; porém, essa identificação não é gratuita: só é na responsabilidade que a liberdade acha sua condição e sua razão de ser. É, então, evidente 
afirmar que ausência de responsabilidade haverá de ser idêntico a afirmar ausência de liberdade (Szasz, 1994).

Podemos agora retomar a pergunta que formulávamos no início: é possível imaginar e propiciar a criação de um saber médico que, renunciando a ser um instrumento de controle, possa afirmar-se num espaço solidário de vínculos legítimos entre iguais?

Se tomarmos como ponto de partida a crítica dos conceitos de compaixão e piedade aqui esboçada, quiçá possamos nos aventurar em uma primeira resposta, necessariamente parcial e fragmentária, para essa questão. De nossa leitura dos textos de Nietzsche e Hannah A rendt podese concluir, em primeiro lugar, que, no âmbito da assistência ou do saber médico, não deveria existir nenhum espaço reservado para a compaixão ou a piedade. Pois, a partir do momento no qual a "razão terapêutica" se apresenta a si própria como compassiva, corremos o risco de reforçar a dependência do paciente e, conseqüentemente, desestimar sua capacidade de decisão, de ação, de eleição e de diálogo refletido.

A razão terapêutica deve enfrentar-se quase inevitavelmente com sujeitos que se consideram a eles próprios como prisioneiros da debilidade que o sofrimento impõe, torna-se indispensável que o saber médico apele a estratégias capazes de impedir que essa sujeição inicial (muitas vezes inevitável) se possa converter em passiva aceitação; isto é, na naturalização de relações dissimétricas de poder. Contrariando esse pressuposto, a lógica da compaixão demonstrou uma notória eficácia como instrumento capaz de garantir e reforçar essa dissimetria inicial.

Segundo assinalamos, a compaixão é silenciosa, refratária às palavras e a qualquer forma de diálogo. A comiseração, fundada neste reconhecimento imediato, pode falar por gestos, olhares ou carícias, mas nunca apelará para argumentos pelos quais uma intervenção médica sobre nosso corpo possa se tornar inteligível e conseqüentemente passível de ser aceita ou de ser rejeitada. Desde que a compaixão parte do pressuposto de que é pela sua mediação que as pessoas se aproximam e que se podem apagar as distâncias, as palavras viram supérfluas. Porém, é mister reconhecer que, na condição de sofredores, quando nos enfrentamos com o limite da dor, sempre nos assumimos como "diferentes"; reconhecemo-nos participando de uma pluralidade humana que rejeita as homogeneizações. Por meio da experiência individual do sofrimento nos reconhecemos como únicos e insubstituíveis, como diferentes; mas, ao mesmo tempo, essa experiência nos torna partícipes da condição humana, como condição universal.

Todos compartilhamos dessa capacidade propriamente humana de 
padecer dor e de temer a morte, mas sabemos que somente a capacidade humana de falar, de dizer, pode ser equiparada a ela, em universalidade e singularidade. Pois, por meio do diálogo e da argumentação, podemos fazer que nossas experiências mais íntimas possam ser enunciadas, adquirindo assim inteligibilidade tanto para mim quanto para os outros. É pela mediação dessa capacidade dialógica, que define e possibilita a existência da pluralidade humana, que nos podemos deter em pensar sobre nossa vida e nosso corpo. Por isso, se admitirmos que o que caracteriza nosso pensamento é seu caráter discursivo, então só será pela mediação da palavra trocada com outros que poderemos confrontar nossas crenças com pontos de vista diferentes e ainda antagônicos aos nossos. Só então haverá de ser possível a enunciação de nossas dúvidas e de nossos medos, tentando atingir certo grau de inteligibilidade e certa capacidade de decisão sobre nossa situação.

Todos estamos sujeitos à dor, à doença e todos tememos a morte, porém, essa experiência, longe de nos unificar, banindo as diferenças, nos enfrenta com o fato incontestável de uma pluralidade de experiências e de pareceres sobre quais temos o direito e a obrigação de refletir.

Por interessantes que as coisas do mundo apareçam, por mais profundamente que possam nos emocionar e estimular, elas não se tornam humanas para nós até o momento em que possamos discuti-las com nossos semelhantes. Tudo o que não pode ser objeto de diálogo pode muito bem ser sublime, horrível ou misterioso, mas não é verdadei ramente humano. Humanizamos o que passa no mundo e em nós, quando falamos, e com esse falar aprendemos a ser humanos. (A rendt, 1980, p.25)

Nesse instante, em que pela força da compaixão a razão terapêutica silencia todas as palavras, a partir do momento em que o co-sofrimento mudo substitui os argumentos, e que a proximidade do sentimento anula as distâncias e as mediações que o diálogo pressupõe, corremos o risco de reforçar formas coercivas de assistência. Então, é a própria humanidade que fica entre parênteses. 0 co-sofrimento excluirá a razão terapêutica do âmbito do propriamente humano, inserindo seus atores num mundo que bem poderá vir a ser de deuses ou de escravos, mas que, dificilmente, haverá de ser um mundo de homens. Um mundo transido pelo dizer e pelo fazer humanos; os únicos capazes de gerar vínculos simétricos que excluam a coerção e a violência.

Lembremos aqui Platão, que, em As leis, pela primeira vez, propõe distinguir uma medicina inteiramente empírica, que prescinde da argumentação, da persuasão e do vínculo dialógico, e uma medicina preocupa- 
da com a instauração de um diálogo simétrico entre sujeitos que se reconhecem como iguais, onde não se pode prescindir da força, da argumentação e da persuasão. A medicina, para que possa ser considerada sábia e não puramente empírica, precisa:

trocar opiniões com o próprio doente e seus amigos e próximos, e, ao mesmo tempo que (o médico) aprende junto aos doentes, instrui, na medida do possível, o próprio paciente, sem Ihe prescrever nada ... e, assim, auxiliado pela persuasão, acalma e prepara continuamente seu paciente, até conseguir restituir, pouco a pouco, sua saúde. (Platão, 1980, p.720).

Só então é possível falar de uma medicina que homens livres exercem em benefício de homens livres, tendo superado desse modo os limites que impõem uma medicina de escravos, dirigida a escravos. Esta última caracteriza-se, em troca, pelo fato de ser expeditiva e prescritiva, sempre segura, sem deixar lugar para a reflexão ou as dúvidas:

nenhum destes médicos dá nem aceita explicação alguma sobre os casos individuais dos diferentes servos, mas prescreve aquilo que sua experiência sugere, como se estivesse perfeitamente informado, adotando a postura de um tirano, e após isso, apressa-se em atender outro doente. (Ibidem)

Entre ambas as medicinas existe uma diferença essencial, a exclusão da palavra trocada e, conseqüentemente, a eliminação do direito de fazer de nossa própria dor alguma coisa inteligível, algo em relação ao qual possamos ter uma opinião e um julgamento. Karl J aspers (1988, p.61), citando esse texto de Platão, lembra uma velha história segundo a qual, estando doente, Aristóteles interrogou o médico que lhe deu uma terapia dizendo: "mostra as razões de teu fazer, e, se as achar razoáveis, então as haverei de seguir".

A exclusão do âmbito do saber médico, de "razoáveis perguntas e de razoáveis respostas", faz dele algo inapelável e, conseqüentemente, aproxima-o das legislações tirânicas (Platão, 1980, p.857). Assim, na medida em que pretendermos fundamentar a assistência médica pela compaixão, que pela sua lógica interna exclui a mediação do diálogo razoado, corremos o perigo de aproximá-la de formas de ação tirânicas.

Talvez seja por isso que essas estratégias mudas e coercivas que se exercem sobre os corpos (pensemos na medicalização e hospitalização dos "loucos" ou dependentes) insistem em apresentar-se como formas compassivas e piedosas de socorro e assistência. Se, tal como propusemos no início, desconsiderarmos a existência de uma estratégia 
maquiavélica, que se apresenta como compassiva para poder exercer mais livremente seu poder, constataremos que existe uma solidariedade nãoenunciada entre a lógica própria da compaixão piedosa e essa racionalidade utilitarista, estruturada segundo parâmetros de urgência social e de bemestar geral, que está por trás das mais diversas instituições de controle social.

Tanto a razão utilitarista quanto a compaixão piedosa partem de uma certeza. Sempre agem invocando o nome e o bem daqueles que dizem assistir. A mbas conhecem esse bem de um modo claro e distinto, ainda antes de que seja solicitado. A mbas prescindem de argumentos, excluem as palavras e silenciam qualquer diálogo fundado em perguntas e respostas razoáveis. A primeira, à medida que substitui essas razões pelas normas inapeláveis que prescreve. A segunda, pela força do sentimento compartilhado, que aproxima os sofredores, sem necessitar da mediação de argumentos. Como afirma Nietzsche (1984, p.338), o compassivo nada entende de razões, "o coração o manda socorrer e ele acredita fazê-lo melhor, quanto mais imediato for o socorro".

Por isso acreditamos que é possível pensar que não é por ironia, mas sim por estrita complementaridade, que os filantropos podiam insistir em apresentar suas instituições disciplinares sob a retórica da compaixão. Ali, pretendia-se moldar os corpos, multiplicar sua docilidade e sua força, mas ao fazê-lo procura-se integrar os "desviados" sob um olhar médico capaz de restituí-los ao mundo da saúde e da normalidade. Uma normalidade na qual, pela arte do socorro e da caridade, todos os homens possam confraternizar, libertando-se assim dessa "repugnância inata" que gera o sofrimento de um semelhante.

Quiçá seja essa complementaridade que explique as razões desse contrato tácito que possibilitou o nascimento da clínica. Contrato pelo qual se articulam de um modo indissolúvel "o hospital onde se cura os pobres e a clínica, onde se formam os médicos" (Foucault, 1986, p.125). Já no início, a hospitalização caridosa dos pobres e a emergência da clínica complementam-se uma à outra. Enquanto o pobre se beneficia de uma assistência gratuita, o saber médico tem sua retribuição na possibilidade de aprender, observar e lecionar, por meio de um olhar atento que se dirige ao espetáculo que os corpos doentes representam. Haverá de ser esse saber que, mais tarde ou mais cedo, poderá beneficiar os benfeitores compassivos, pois será aplicado na cura de suas futuras doenças. "O que é benevolência a respeito do pobre transforma-se em conhecimento aplicável ao rico" (Ibidem, p.127).

Com o nascimento da clínica, a distinção platônica antes aludida, 
começa a deixar de ter significação. A partir dali, tudo ficará sob o registro de um olhar médico que desloca, pouco a pouco, a persuasão, a argumentação e o diálogo, agora também do mundo dos cidadãos livres. Esse olhar, juntamente com o nascimento do hospital medicalizado (seu complemento indissociável), contribuíram para que possam vincular-se e reforçar-se três modos diferenciados e privilegiados de medicalização que ainda subsistem. Como afirma Foucault:

A assistência médica do pobre, o controle da saúde da força de trabalho e a indagação geral da saúde pública protegem as classes mais ricas dos perigos (sanitários) gerais e também permitem a construção de três sistemas médicos superpostos e coexistentes: uma medicina assistencial voltada aos mais pobres, uma medicina administrativa, encarregada de problemas gerais como vacinas, epidemias etc. e uma medicina privada, que visava beneficiar a quem tinha os recursos para pagar. (1993, p.153)

Se nos perguntarmos agora pela medicina assistencial dedicada aos pobres, e retomarmos as críticas dirigidas ao conceito de compaixão aqui esboçadas, deveremos perguntar também pelo conceito de "piedade" que, segundo Hannah A rendt, constitui seu equivalente genérico. Nossa crítica, até o momento, ficou na tentativa de desestimar a legitimidade de uma assistência médica fundada na compaixão. Mas se tentarmos generalizar essas observações (referidas ao vínculo individual existente entre assistente e assistido) para estruturas gerais comprometidas com o bem-estar social e com a saúde pública, dever-nosemos negar a aceitar, do mesmo modo, toda intervenção fundada no conceito de piedade.

Os perigos decorrentes da extrapolação do sentimento de compaixão para o largo mundo dos que sofrem são:

a) Na medida em que a piedade já não é um co-sofrimento silencioso que, assim como a compaixão, pertence ao âmbito do privado, no momento que ela precisa ser enunciada e declarada publicamente, deve expor no âmbito do público aquilo que estava reservado para a intimidade do sentimento. Essa bondade que agora precisa ser obsessivamente declarada e insistentemente enunciada pode converter-se em seu oposto: na hipocrisia, na falsidade e na perseguição.

b) Por tratar-se de um sentimento, a piedade leva em si própria seu prazer. Assim, na medida em que se refere à massa dos fracos e se desvincula do co-sofrimento privado, pode terminar glorificando essa mesma debilidade que é sua condição material de existência. Desse 
modo, o sofrimento, que é sua causa imediata, se pode converter num mal que é necessário para que exista o bem.

Segundo Hannah A rendt, a partir dessa enunciação da piedade como virtude, os modernos Estados benfeitores acabam por negligenciar o valor da liberdade. Foi assim como a Revolução Francesa finalmente assumiu como objetivo a abundância e não a liberdade (A rendt, 1990, p.51). A partir dali o Estado moderno promete o fim do sofrimento e da escassez, porém, essa promessa não realizada fala de outra perda que não é reclamada: já não se procura criar instituições capazes de quebrar os vínculos coercivos que nos prendem aos outros.

De modo semelhante, Foucault soube mostrar como essas instituições de assistência que, em nome da segurança, do bem-estar e da assistência aos necessitados, emergem após a Revolução Francesa, geraram mecanismos de controle e sujeição antes inconcebíveis. Em diferentes estudos genealógicos esta análise será levada até o limite de mostrar que estes novos saberes, preocupados com o bem-estar da população, como a assistência social ou o saber médico, constituem estratégias efetivas de poder. Para manipular aqueles sujeitos que fogem à categoria médico-jurídica de "normalidade" e moldar sua vontade conforme fins precisos e socialmente eficazes, estes saberes sustentam-se em mecanismos coercivos, porém socialmente admitidos.

Digamos, por fim, que o perigo, inerente a uma assistência pública que se apresente como piedosa, consiste em que, por trás da repetição dessa velha promessa sempre postergada de garantir o bem-estar geral, ela se contenta com reforçar a sujeição dos corpos, pela mediação das biopolíticas. Tanto o auxílio técnico-administrativo referido à pobreza quanto uma assistência apta para cobrir as demandas de saúde da população devem rejeitar qualquer apelo à piedade e propiciar uma solidariedade efetiva entre iguais. A solidariedade, no momento em que pressupõe a pluralidade humana, precisa da mediação do diálogo e da argumentação razoada. Fica excluída, portanto, qualquer generalização que unifique a pluralidade dos que sofrem negligenciando sua singularidade e sua individualidade. Só assim poderemos assumir o lugar desse outro que sofre e que reclama seu direito a ser assistido; desse outro que (mesmo quando seus interesses possam ser contrários aos meus) reconhecemos como alguém que é um semelhante em orgulho e dignidade. Tratase, enfim, de "colocar o respeito acima da compaixão" (Szasz, 1994, p.306), a solidariedade acima da piedade.

CAPONI, S. The logic of compassion. Trans/Form/A ção (São Paulo), v.21-22, p.91- 
117, 1998-1999.

- ABSTRACT: Taking the works of Nietzsche, A rendt and Foucault as starting point, we analyze the endogenous logic to the notion of pitiful compassion which instrumentalists a peculiar form of power captured by the duality serve-obey. From the perspective of this authors, we provide examples that history presented to illustrate the deployment of "cruel compassion".

- KEYWORDS: Compassion; Nietzsche; power.

\section{Referências bibliográficas}

ARENDT, H. Vidas políticas. Madrid: Taurus, 1980.

. A revolução. São Paulo: Ática, 1990.

. Verdade e Política. In: Entre o passado e o futuro. São

Paulo: Perspectiva, 1992. . La condición humana. M exico: Siglo XXI, 1993.

ARISTÓTELES. Ética a Nicómaco. Buenos Aires: Aguilar, 1980.

COLIÉRE, M. F. Promover a vida. Lisboa: Printempo, 1989.

DE GERANDO, B. Le visiteur du pauvre. Disciplines à Domicile. Recherches, n.28, 1977.

FOUCAULT, M. El nascimiento de la clínica. México: FCE, 1986. . La vida de los hombres infames. Madrid: La Piqueta, 1993.

HIM MELFARB, G. La idea de la pobreza. M éxico: FCE, 1986.

J ASPERS, K. La práctica médica en la era tecnológica. Barcelona: Gedisa, 1988. NIETZSCHE, Genealogía de la Moral. Valencia: Sempere, 1920. . Aurora. México: EMU, 1978. . La gaya ciencia. Madrid: Sarpe, 1984.

PLATÓN. Las leyes. In: Obras Completas. Madrid: Aguilar, 1980.

ROSEN, G. Da polícia médica à medicina social. Rio de J aneiro: Graal, 1980. ROUSSEAU, J. J. Discurso sobre el origen de la desigualdad entre los hombres.

Buenos Aires: Hispamérica, 1984.

SZASZ, T. Cruel compaixão. Campinas: Papirus. 1994. 